\title{
EFFICIENCY OF IMPLEMENTING SANCTIONS IN CASE OF POLYGAMY IN THE MODERN ISLAMIC WORLD
}

\author{
M. Samson Fajar ${ }^{1 *}$, Abdul Qadir Jaelani \\ ${ }^{1,2}$ Faculty of Law, Universitas Muhammadiyah Metro Lampung, Indonesia \\ E-mail: ${ }^{1)}$ ibnuummi@gmail.com
}

\begin{abstract}
Reform of family law is necessary, and this has become a trend in the renewal of Islamic family law in the modern world. One of the themes studied is the application of legal sanctions (criminalization). Criminalization is a product of modern law, which is very different from the fiqh law, which refers to society. In this study, polygamy is the theme that will be discussed. How is the implementation of criminal sanctions in cases of polygamy in some modern Muslim countries? The country objects that are the focus of the study are Indonesia, Malaysia, and Tunisia. The study approach uses a comparative approach, including vertical comparison (state law-classical legal doctrine), horizontal comparison (Law between countries), diagonal comparison (level of legal dynamics). Results in two conclusions that polygamy as a study of Islamic family law is a private matter and a public issue, so it requires firmness of sanctions. There are two views that polygamy law is prohibited and allowed with conditions, as for those who prohibit it, Tunisia by imposing criminal sanctions and those who allow it on condition that Indonesia and Malaysia, by imposing light sanctions.
\end{abstract}

Keywords: Criminalization, Polygamy, Modern Islamic World

\section{INTRODUCTION}

One trend of family law reform in the modern Islamic world is implementing legal sanctions (criminalization). The move from classical law, which tends to have no legal sanctions. The example switches to state product laws and regulations, limiting and complicating and even prohibiting and categorizing a problem surrounding family law as a criminal act.

For example, in the case of polygamy, although the criminalization of polygamy has not yet become a general portrait of the laws/laws that apply in Muslim countries, its existence is increasingly being considered. It remains one of the hot topics of the Muslim world today.

It is interesting if the criminalization of polygamy in Indonesia can also be examined more closely. Moreover, see how other Muslim countries apply it, then compared it with each other in the context of conventional Islamic law doctrine, between countries, and its position as one of the images of dynamics in Islamic Law, especially law. Modern Muslim State family. Similarly, when compared with legal policies in non-Muslim countries (Western countries).

As mentioned in the title above, this paper only focuses on studies in several Muslim countries: Tunisia, Malaysia, and Indonesia, using a comparative approach, including vertical comparison (state law-classical legal doctrine); horizontal comparison (Law between countries); diagonal comparison (level of legal dynamics). 


\section{IMPLEMENTATION METHOD}

The method utilized in this study is descriptive qualitative through library research techniques, and literature studies reviewed from the latest journals that discuss the application of criminal sanctions in cases of polygamy in several modern Muslim countries. The country objects that are the focus of the research are Indonesia, Malaysia, and Tunisia. The study approach uses a comparative approach, including vertical comparisons (classical law doctrines of state law), horizontal comparisons (law between countries), diagonal comparisons (level of legal dynamics).

\section{RESULTS AND DISCUSSION}

\subsection{The Enforcement of Sanctions for Polygamy Practices in the Modern Islamic World}

One of the steps to reform Family Law in modern Muslim countries is to review several provisions of classical Islamic Law that are considered irrelevant to social conditions and modern demands/changes. The same is true in the case of polygamy. Conventional fiqh rules have been a reference for centuries are being reviewed and replaced with legislation products that seem to be directed at elevating the status of women and responding to the demands and developments of the times.(Buxbaum, 1968)

In general, the provisions (laws) relating to family law in modern Muslim countries related to polygamy rules can be classified: first, countries that prohibit polygamies, such as Turkey and Tunisia entirely. Second, countries that allow polygamy with relatively strict conditions (complicated) include Pakistan, Egypt, Morocco, Indonesia, and Malaysia. Third, countries that treat polygamy more loosely, such as Saudi Arabia, Iran, and Qatar (Mahmood, 1987)

The second category is the general trend of Family Law in the Islamic World of the three categories(Mahmood, 1972). Restrictions on polygamy are varied, from the most lenient to the strictest. For example, in Lebanon, under the family law imposed by the Ottoman Empire in 1917, polygamy is not prohibited but is expected to apply the principle of justice to wives. Things that are not much different also happen in Morocco under the Personal Status Act of 1958, which applies there (Mahmood, 1987).

Another way to limit polygamy is by contract. The wife is given the right to ask her husband when getting married to agree that if it turns out that later he remarries to another woman, the wife can immediately ask for a divorce from the Court or automatically divorce one if the one violates it is the wife. It is mentioned, for example, in article 19 of the Jordanian Family Law No. 61 of 1976 as amended by Jordanian Family Law No. 25 of 1977. The same is also stated in article 31 of the Moroccan Personal Status Act of 1958 (Mahmood, 1987).

As seen in the last example mentioned, the practice of polygamy has even been categorized as an act that is subject to certain legal sanctions. In other words, some Muslim countries have criminalized the practice of polygamy in their Family Laws. As mentioned in the previous discussion, at least 8 Muslim countries have imposed legal sanctions on the issue of polygamy in their family law. The eight countries are Iran, Pakistan, Yemen (South), Iraq, Tunisia, Turkey, Malaysia, and Indonesia.

As for the criminalization of polygamy in family law in the three last-mentioned countries, which serve as models for this study, it will be described in more detail in the following discussion:

1. Tunis

After independence on March 20, 1956, Tunisia immediately compiled various legal reforms and codifications based on the Maliki and Hanafi schools. This reform effort is based on a liberal interpretation of sharia, especially concerning family law. be bornMajallat al-Ahwal ashShak;iyyahcontroversial. Under the leadership of President Habib Bourguiba, Tunisia became the first Arab country to ban polygamy.(Safra \& Yeshua, 2003)

Majallatit self includes material on the law of marriage, divorce, and child-rearing, which is different from the provisions of classical Islamic Law. In subsequent developments, the Majallat or 


\section{POLICY, LAW, NOTARY, AND REGULATORY ISSUES (POLRI) VOLUME 1 ISSUE 1 (2022)}

Personal Status Act of 1956 has undergone several changes, additions, and further modifications through amendments to the Act until 1981. Furthermore, the Tunisian government formed a committee under the supervision of Sheikh al -Islam, namely Muhammad Ju'ayad, to enforce the law officially.

The Sheikh of Zaituna University also participated in the committee. By using the sources obtained from the results of the Lai'hat committee, family law in the style of Egypt, Jordan, Syria, and the Ottoman Turks. The committee submitted a draft family law bill to the government, and the law was finally enacted in 1956.

The law consists of 167 articles written in 10 volumes considered quite comprehensive, although it does not yet contain laws regarding inheritance. This law was amended seven times during the period 1958-1966. The last time this law was amended was in 1981 (UU No. 7/1981), which introduced several essential modifications to the previous law.

There are several reasons for the formation and enactment of the new Tunisian law, namely:

1) To avoid conflict between Hanafi and Maliki thinkers;

2) For the unification of courts into national courts, so that there is no longer any difference between religious courts and district courts;

3) To form modern laws, as a reference for judges;

4) To unify the views of society as a whole due to differences from the classical schools;

5) To introduce new laws that suit the demands of modernity (J. N. D. Anderson, 1959)The Tunisian law applies to all Tunisian citizens, especially after an agreement was reached with France on July 1, 1957. From the various reforms in this new law, two things (initially) received a negative response from several circles, namely the prohibition of polygamy. And the necessity of divorce in Court (Gupta, 1992).

Regarding the criminalization of polygamy in Tunisia, article 18 states:

a. Polygamy is prohibited; anyone married before his first marriage ends, then remarries, will be sentenced to one year in prison or a fine of 240,000 malim or both.

b. Who is married violates the rules in Law no. 3 of 1957 , which relates to city regulations and a second marriage contract; while he is still bound by marriage, he will be subject to the same punishment.

c. According to unofficial provisions, anyone who knowingly marries someone subject to punishment can also be subject to the same punishment.

The Tunisian Law on the Status of Individuals of 1957 expressly stipulates that polygamy is prohibited. This prohibition is said to have a legal basis in another verse in the Qur'an, which states that a man must marry a wife if he believes he is unable to do justice to his wives (Surah an-Nisa [4]: 3). It turns out, both from experience and revelation statements (Surah an-Nisa [4]: 128), the justice in question will not be fulfilled. However, it should be added that the fuqaha the salaf, with reasonable grounds, states that the Qur'an cannot simply be regarded as contradicting itself. Furthermore, the justice demanded by the "polygamy verse" must be interpreted as things a husband can do and not his inner feelings (love).

Tunisia puts forward two reasons for the prohibition of polygamy: first, that the institution of slavery and polygamy is only allowed during the developmental or transitional period of Muslims, but is prohibited during the developmental period or in a cultured society; and second, that the absolute condition for polygamy is the ability to treat the wife fairly, while historical facts prove only the Prophet. Capable of running, I am fair to his wives (N. Anderson, 1976).

Before this law, the qadi in Tunisia consisted of qadi from the Hanafi school and the Maliki school, although the people in general adhered to the Maliki school. However, this eclectic new law has been declared to apply to all Muslims (and has been further accepted by and has been declared to apply to Jews) so that all courts are united. All types and jurisdictions of the judiciary are in the 
hands of the national courts. President Bourguiba openly stated, "ideas prevailed in the past, today are contrary to human conscience. for example, about polygamy and divorce which are now regulated by the new law, as well as all the problems that arise in modern life. at the moment." He stated that Islam had liberated the soul and ordered people to review the religious laws to adapt them to the progress made by humans. This statement is very different from the views of the salaf.(Cayne, 1969)

In addition, the reformers in Tunisia emphasized that a husband must have the financial ability to support his wives, and the Koran also requires polygamists to treat them fairly. This Quranic rule must also be interpreted as a moral imperative and as a precedent for the legal condition for polygamy, in the sense that no second marriage can be permitted unless and until it is proven to be equally (egalitarian) where the wives are treated fairly. However, looking at current social and economic conditions, it seems that fairness is an impossibility. When the primary conditions of polygamy cannot be met, Tunisian Law briefly states, "polygamy is prohibited." (J. N. D. Anderson, 1959).

Tunisia can be considered a leading example of how, after 1945, reforms tended to be based more on what was stated to be the right of Muslim states, through their rulers, to ijtihad. Tunisia abolished the right to polygamy through Article 18 of the Tunisian Personal Status Act 1956, based on a reinterpretation of Surah an-Nisa verse 3. Tunisia equates justice not only with livelihood (financial support) but also with love and compassion. It is also stated that only the Prophet. Who can do justice to two wives in this way; Therefore, in the current situation, the undeniable assumption is that a Muslim husband cannot fulfill the requirements of the Koran (Newby, 1991).

\section{Malaysia}

In the context of family law reform, especially in Southeast Asia, it may even be that the scope of the Muslim world is Malaysia as the first country to take this step, marked by the birth of Mohammedan Marriage Ordinance, No. V Year 1880in the strait countries (Pulau Pinang, Malak, and Singapore). The allied Malay countries continued (Perak, Selangor, Negeri Sembilan, and Pahang) through Muhammadan Marriages and Divorces Enactment 1885. then for the non-allied Malay countries or the shelter countries (Kelantan, Terengganu, Perlis, Kedah, and Johor), which Kelantan pioneered is The Divorce Regulation of 1907 (Nasution, 2003).

However, when viewed from the era after the end of colonialism and imperialism, Malaysian legislation has undergone several reforms. Taher Mahmood noted that the first reforms occurred in 1976-1980, which dealt with marriage and divorce. At the same time, the second renewal was carried out in 1983-1985, which was named Islamic Family Law Act. This new law came into effect in 1983 in Kelantan, Negeri Sembilan, and Malacca. Then in 1984, it was held in Kedah, Selangor, and the Alliance area, and in 1985 it was held in Penang. In recent developments, reforms have also occurred in Terengganu (1985), Pahang 1987 (No. 3), Selangor 1989 (No. 2), Johor (1990), Sarawak (1991), Perlis, and finally Sabah through Law no. 18 of 1992.

Regarding the criminalization of polygamy in positive Law in Malaysia, among others, it is illustrated in the 1984 Law on Islamic Family Law [Federal Territory] (UU 304 of 1984). Article 123 states:

During subsistence a marriage, any man contracts another marriage any place, without the prior permission in writing of the Court. Commits an offense and shall be punished with a fine not exceeding one thousand ringgit or with imprisonment not exceeding six months or with both such fine and imprisonment.

That confirms that a man who is still bound in a marriage can only be polygamous if he has obtained written permission from the Court. Those who violate the provision will be sentenced to a 


\section{POLICY, LAW, NOTARY, AND REGULATORY ISSUES (POLRI) \\ VOLUME 1 ISSUE 1 (2022)}

maximum fine of 1000 ringgit. Alternatively, imprisoned for a maximum of 6 months or sentenced to both at the same time.

The granting of a polygamy permit by the Court is closely related to the results of the institution's consideration of the information given by the applicant and the wives he first married. The basis for the Court's consideration to permit polygamy is related to the condition/behavior of the wife and husband. From the wife's point of view is 1) Infertility; 2) Physical aging; 3) Not physically fit for intercourse; 4) Deliberately not wanting to restore sexual rights, or 5) Mental illness/insane. While the considerations from the husband's point of view are: 1) Economically able to bear his wives and children, 2) Able to treat wives fairly 3) The marriage does not cause danger to the wife's religion, life, body, mind, or property. Been married before,

In general, Malaysian Family Law seems to still adhere to the conception of the Sunni schools, especially the Shafi'i school, in terms of the permissibility of polygamy. The stipulation of several reasons for polygamy seems to be inspired by the fiqh conception of the husband's obligation to his wife and the reasons for the occurrence of Faskh. Meanwhile, the role of the Court in granting polygamy permits and criminalizing polygamy is part of the form of sharia Siyasa, which aims to anticipate and provide a deterrent to the abuse of polygamy. In addition, a new interpretation of the message of the Koran regarding the issue of polygamy and protection measures for women is also an inherent part of the fundamental reasons for enacting these articles.

\section{Indonesia}

Before enacting Marriage Law No. 1/1974 in Indonesia, a Muslim man is relatively easy to polygamous marriage. He was only asked to report his new marriage to the marriage registrar and be fair to his wives. Substantially, the Marriage Law changes this situation, although it is still ambiguous. On the one hand, the principle that marriage is a monogamous institution is considered to have underpinned such legal provisions (Article 3); indeed, one of the main objectives of the Marriage Law is to reduce the rate of polygamous marriages. On the other hand, the law allows a man to have more than one wife if he can fulfill the requirements of several provisions of the law, is permitted by his religion, and obtains permission from the Religious Court. Although these rights are maintained, the administrative procedures are not accessible. In general, it limits the possibility of arbitrary use of these rights.

The same provisions are maintained in the Indonesian Compilation of Laws (KHI) established in 1991. The courts in this regard play an essential role in granting permission to husbands to practice polygamy. However, both Law no. 1/1974 and KHI do not include legal sanctions against parties who violate. Sanctions for polygamy are regulated in Government Regulation No. 9 of 1975 concerning the Implementation of Law No. 1/1974; it is stated that polygamy perpetrators without the Court's permission can be sentenced to a fine of Rp. 7.500,-Legal sanctions are also imposed on the registrar who records the marriage of a husband who will have polygamy without the Court's permission with a maximum imprisonment of 3 months or a maximum fine of Rp. 7.500,-.

Meanwhile, relatively heavy penalties are imposed for Civil Servants who practice polygamy outside the stipulated provisions. It is stated in Circular No. 48/SE/1990 regarding the Implementation Guidelines for PP. 45/1990 regarding amendments to PP No. 1983 concerning Marriage Permits and Divorce of Civil Servants that PNS and/or superiors/officials, except for Monthly Employees in addition to retirees. Were sentenced to one of the severe disciplinary penalties based on PP No. 30/1980 concerning Civil Servant Disciplinary Regulations.

Various provisions in the Marriage Law no. 1/1974 and the KHI regarding polygamy above basically do not contradict the concept of conventional schools, including the Shafi'i school. Similar to Malaysian Family Law, the requirements for a husband who wants to be polygamous are also related to the husband's obligations regulated in the traditional fiqh conception, namely the 
ability to provide a living and treat wives fairly. Likewise, the emergency condition of the wife who was married seems to exist related to the cause of the Faskh. The legal product is oriented to elevate the status of women and provide protection before them, something in line with the spirit of the Qur'an and Sunnah of the Prophet.

Although now polygamous marriages have been and are likely to become a rare occurrence in Indonesia, the effectiveness of polygamy laws still seems to be in doubt. Among the contributing factors are legal sanctions for violating this law, a fine of Rp. 7,500,- or three months in prison, is considered not according to current conditions. The penalties are not harsh enough to prevent violations of the law. In addition, there is still a legal dualism in Indonesia: traditional Islamic Law versus state law, resulting in polygamists preferring to take refuge in traditional Islamic Law, which legitimizes polygamy without worrying about being punished as imposed by "state product" Islamic law.

\subsection{Comparative Analysis}

What is often used in analyzing comparative data is vertical, horizontal, and diagonal comparison analysis. This analysis is explained by Atha' Mudzhar in his paper, what is meant by a vertical analysis comparing the rules enforced in these countries with the opinions of fiqh scholars when there is a difference then what is the normative basis of fiqhiah so that a new opinion emerges. In comparison, the horizontal analysis compares the similarities and differences between the countries in the application of the sanctions. The diagonal analysis places these countries in order and level in terms of whether the regulation is liberal. In this case, in the application of sanctions.

In the first vertical analysis, the three countries above have departed from the classical fiqh understanding, which essentially does not have a problem with polygamy. Even when the wife does not allow it, it is not a problem for the husband to polygamy. Also in polygamy does not apply stringent conditions as made by these countries. In the perspective of the madhhab, Imam Malik, in his al-muwatha, allows polygamy up to four. While as-Shafi'i in al-Umm, he also allows polygamy based on the Qur'an and as-Sunnah.Likewise, Ibn Qudamah allows polygamy a maximum of four. In short, the priests of the madhhab require fairness in terms of material and share the night.

As for the horizontal analysis, the strictest prohibition of polygamy is in Tunisia because polygamy is a tradition. However, this is getting massive protest at this time. The President of the Freedom and Citizenship Forum, Fathi Al-Zghal, confirmed the protests were spontaneous and came to resolve polygamy in Tunisia. Al-Zghal supports the idea of protesting because he believes there is a need for a solution to the lives of single women in Tunisia.

According to Al-Zghal, the Personal Status Law, which regulates women's rights and freedoms in Tunisia, needs to be reviewed. Polygamy matters and divorce procedures need to be reviewed because they are considered contrary to Sharia law (Tempo: 2019).

According to a recent report published by the National Agency for Family and Population Affairs in December 2017, Tunisia is one of the countries with the highest rates of marriage reluctance, with a figure of 60 percent much higher than the ratio of other Arab countries.

The report reveals that single women have risen to more than 2.25 million out of 4.9 million women in Tunisia. This figure has increased from just 990,000 in 1994, with the highest gestational age among women ages 25-34.

In this case, essentially, the imposition of criminal sanctions on Tunisian society creates new problems and requires reconstruction because polygamy has finally become a solution to the personal problems of society, especially women.

Meanwhile, Malaysia and Indonesia provide various conditions for polygamy, so they seem indecisive. This is because Indonesia and Malaysia are still very much influenced by the normativity of the Shafi'i madhhab. However, in terms of implementing sanctions, Indonesia is the 


\section{POLICY, LAW, NOTARY, AND REGULATORY ISSUES (POLRI) \\ VOLUME 1 ISSUE 1 (2022)}

lightest, so this does not deter polygamy perpetrators. There are many irregularities in sirri marriages in Indonesia because there is no firmness of the sanctions.

In the author's opinion, the rule of Indonesian law is excellent; by providing a wide but regular space, violations of polygamy sanctions are not for polygamy implementers but for those who violate their rights in family life. Indonesia and Malaysia are culturally shafi'i schools that firmly hold this tradition. Even historically, many umara', ulama' have done this. The imposition of sanctions, in general, will only create new problems as in Tunisia.

The last analysis is a diagonal analysis between countries. Tunisia, which prohibits polygamy, is the country that shows its liberalism in thinking by jumping away from the classical fiqh concept. Even the perpetrators are subject to legal sanctions. They were then followed by Malaysia, which is more assertive than Indonesia. However, there is not too much difference between Indonesia and Malaysia because it is related to culture and territory

\section{CONCLUSION}

Islamic family law turns out to be not only a conception of fiqh that applies individually without sanctions, so the concept of fiqh is complicated to bind people's lives. So, with the trend of canonization of Islamic Law in several modern Islamic countries both in Tunisia, Malaysia, and Indonesia, this is the progress of Islamic Law in a time full of complex problems.

Polygamy is a fundamental issue to be given rules in Islamic Law because the level of problems in the household is getting higher. From the article above, it can be concluded that there are two views that polygamy law is prohibited and allowed with conditions. As for the prohibition, Tunisia (although the current era is experiencing a new anomaly with large public protests) by imposing criminal sanctions and those who allow it on condition that Indonesia and Malaysia impose light sanctions.

\section{REFERENCES}

Anderson, J. N. D. (1959). Islamic law in the modern world.

Anderson, N. (1976). Law reform in the Muslim world.

Buxbaum, D. C. (1968). Family law and customary law in Asia: a contemporary legal perspective. Martinus Nijhoff Publishers.

Cayne, B. S. (1969). Encyclopedia Americana: International Edition. Danbury, CT.

Gupta, K. (1992). Polygamy-Law reform in modern Muslim states: A study in comparative law. Islamic and Comparative Law Review, 12(2), 114-154.

Mahmood, T. (1972). Family law reform in the Muslim world. NM Tripathi.

Mahmood, T. (1987). Personal Law in Islamic Countries:(history, Text and Comparative Analysis). Academy of Law and Religion.

Nasution, K. (2003). Sejarah Singkat Pembaruan Hukum Keluarga Muslim” dalam M. Atho' 'Mudzhar Dan Khairuddin Nasution (Ed. S).

Newby, G. N. (1991). Family Law" dalam John L. Esposito. The Oxford Encyclopaedia of the Modern Islamic World, jld IV, Oxford ....

Safra, J. E., \& Yeshua, I. (2003). The New Encyclopaedia Britannica (Vol. 2). Encyclopaedia Britannica. 